\title{
Belphégor
}

Littérature populaire et culture médiatique

18-1 | 2020

Regards croisés sur la culture médiatique européenne

\section{Greek popular literature magazines for children and teenagers (1950 - 1967)}

\section{Nikos Filippaios}

\section{(2) OpenEdition}

1 Journals

\section{Electronic version}

URL: https://journals.openedition.org/belphegor/2468

DOI: $10.4000 /$ belphegor.2468

ISSN: 1499-7185

Publisher

LPCM

\section{Electronic reference}

Nikos Filippaios, "Greek popular literature magazines for children and teenagers (1950 - 1967)", Belphégor [Online], 18-1 | 2020, Online since 19 January 2020, connection on 29 June 2021. URL: http://journals.openedition.org/belphegor/2468 ; DOI: https://doi.org/10.4000/belphegor.2468

This text was automatically generated on 29 June 2021.

\section{(c) (i) (9)}

Belphégor est mis à disposition selon les termes de la Licence Creative Commons Attribution - Pas d'Utilisation Commerciale - Pas de Modification 4.0 International. 


\title{
Greek popular literature magazines for children and teenagers (1950 - 1967)
}

\author{
Nikos Filippaios
}

1 Popular literature and popular culture in general have a long and vigorous presence in Modern Greek cultural history. The first phase of Greek popular culture dates back to the first centuries of the Ottoman Occupation, most notably from the 16th until the 18th century. This period is dominated by the so-called "Venetian editions" ("fyllades" in Greek), a body of popular literature that was written, not in the ancient language of the scholars, but in plain Greek ("demotiki") and that was combining eastern with western influences and also a "low culture" with a "high culture" perspective. These works were being published by Greek publishers living in Venice and were being distributed to the Greek-speaking population of the Ottoman Empire by itinerant merchants. Thus, a popular readership was also formed which, although socially and economically diverse, remained distinguished from the scholars ${ }^{1}$. As the 18th century handed over to the 19th, gradually Greek popular literature acquired its modern features. After the establishment of the new free Greek state and the organization of the urban center of Athens, in the middle of the 19th century, all the necessary preconditions were created for the introduction of the, mainly French, "romanfeuilleton". Indeed, popular novel overwhelmed Greek society, but met with opposition from the intellectuals who supported ethnocentric ideas and moral didacticism. Therefore, the first popular novels in Modern Greek were written by simple readers which were divided over between the official national propaganda and the adventurous and sensationalist spirit of the "roman-feuilleton". 


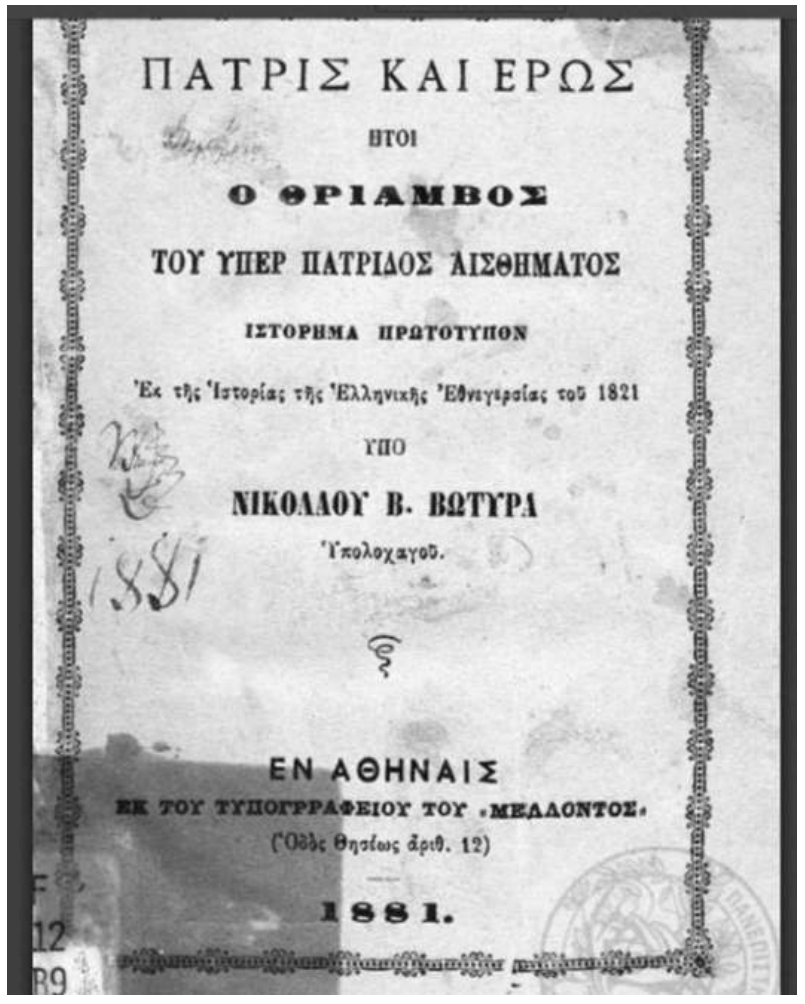

Cover of a representative popular novel of the 19th century. Its title is Homeland and Love and it was written by the military Nikolaos Votiras. The title of the first edition, which was held on 1861, was The sword of vengeance.

2 By the end of the 19th century, the "physical space" of popular culture, namely the press, was developed and organized, thus the area of popular literature was improved. The first professional writers, not only of popular fiction, but also in general, were people of the press, mainly journalists. The trending genre of that time was "the mystery novel", which became famous among the inhabitants of Athens, but also among the Greek-speaking residents of the urban centers of Smyrna and Istanbul. In such a way, Greek popular literature organized and became independent from the "high" literature of the intellectuals ${ }^{3}$. 


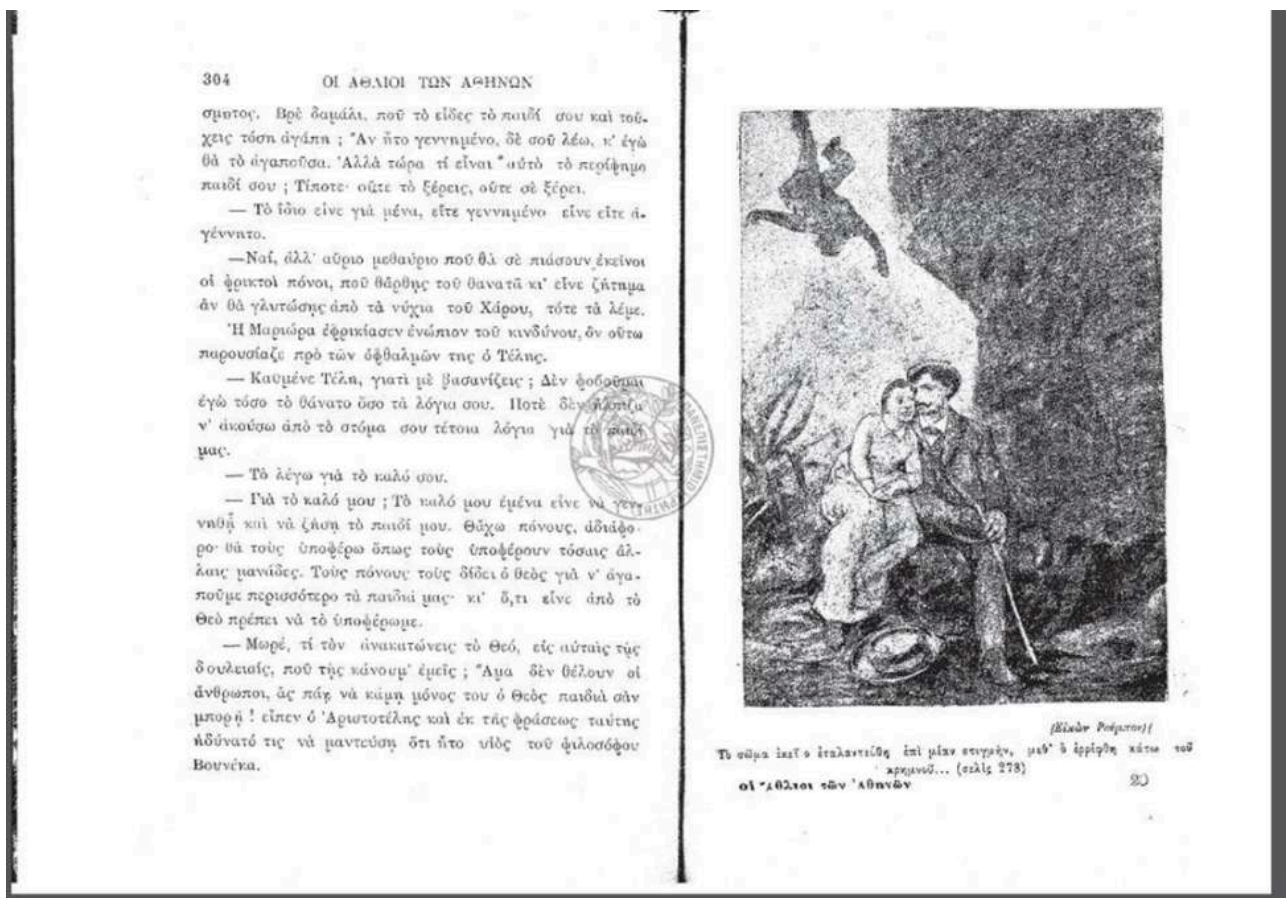

A two-page of the first illustrated edition of the Greek "mystery novel", The miserables of Athens (1895) by loannis Kondilakis; in the picture of the second page, we can vividly see two of the main subjects of the "mystery novel", but also of popular literature in general: love and death

3 These characteristics of popular literature were bequeathed into the 20th century, especially in the genre of the "bandit novel" featuring idealized real and imaginary bandits of Greek countryside. During the period from 1900 to 1920, when "bandit novel" was flourishing, the network of production, distribution and consumption of popular literature became more organized at an even greater extent: many new publishing companies appeared, but they proved to be short-lived, professional writers engaged exclusively with this kind of fiction and, last but not least, Athens became the indisputable center of publishing activity ${ }^{4}$. 


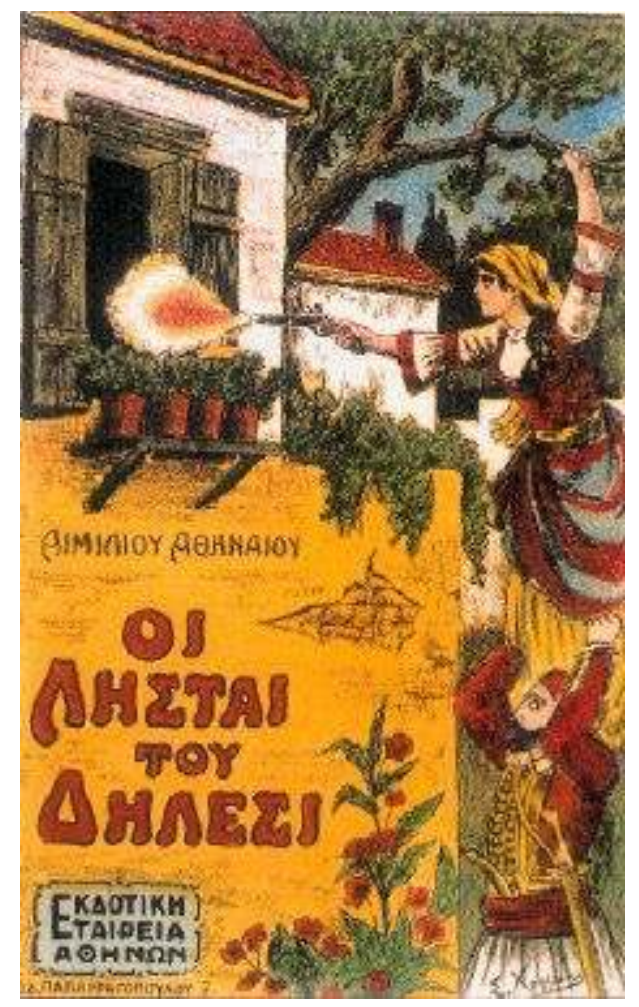

Cover of a bandit novel, entitled The Bandits of Dilesi. It was written by one of the most important authors in this genre, Aristeidis Kiriakos. In this particular novel, he uses the nickname "Aimilios Athinaios" (i.e. Aimilios the Athenian)

4 In parallel with the "bandit novel", during the first decades of 20th century, other genres of popular literature made their appearance, such as crime fiction and sentimental novel. These new genres thrived in the new type of family magazines, released by the major publishers of the time ${ }^{5}$. Our interest focuses more on the genre of crime fiction, because it had a multifarious impact on the popular literature for children and teenagers during 50s and 60s. Crime fiction achieved great commercial success, notably via magazines specialized on this genre; in these magazines, for the first time, we can clearly recognize the dominant influence of American popular culture. In fact, the most successful magazine was called Mask (first released in 1935), a title most likely inspired by the classic American pulp magazine Black Mask ${ }^{6}$. 


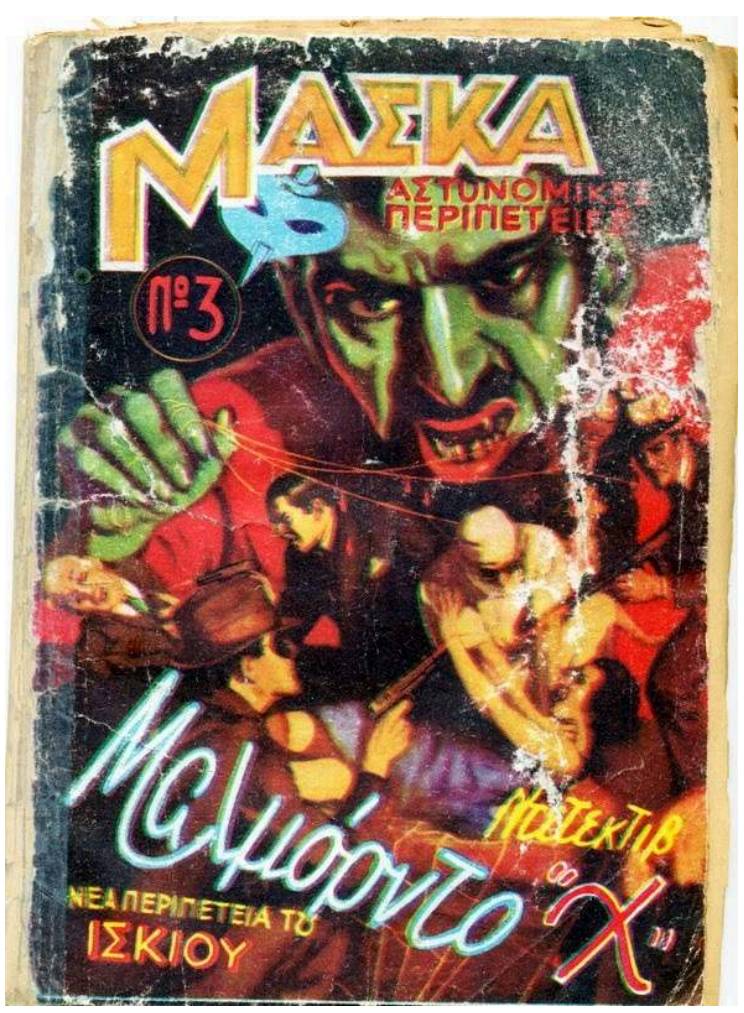

The cover of the third issue of the first publishing period of the Mask magazine, which released in 1946

5 But, during the 40s, as the Greek state entered into a maze of tragic historical events, Second World War, German Occupation and the Civil War that followed, all this rich activity in the field of popular literature recoiled, but it didn't come to a halt. Despite financial and other difficulties, publishers continued to release various magazines and booklets, with frequent references to the current affairs. After the end of the Civil War (1946-49), the whole decade of the 50s was marked by the predominance of the rightwing political forces. As a result, an introvert and conservative ethnocentrism was propagandized and established, especially in the fields of culture and education. On the other hand, the Greek economy gradually developed and also lifestyle and mentalities of a large part of the population, notably the one living in the urban areas, was opened towards the West. Therefore, Greek popular culture as a whole (press, literature, cinema and music) was strongly influenced by the United States.

6 So, when we come to investigate Greek popular literature for children and teenagers during the $50 \mathrm{~s}$ and the $60 \mathrm{~s}$, we should keep in mind both the long and idiosyncratic course of Greek popular culture and the specific social and political circumstances of those decades too. We must also take account of the historical progress of the Greek literature for children and teenagers. An initial interest in the development of literature oriented excursively to children and teenagers was grown during the 19th century, when some litterateurs wrote poems, tales and entire novels in this aspect and also by the release of some short-lived children magazines. But the strongest boost to children's literature was given in connection with the popular one, when some very famous works became part of children's literature canon, for example the novels of Jules Verne. After the second half of the 20th century, literature for children and young adults took two opposite directions: high literature which was promoted by people of 
the educational system, especially teachers and had fundamentally instructive purpose and popular literature, which will be presented below 7 .

7 First of all, the necessary precondition for the development of popular literature especially for children and teenagers is the maximum growth of the network of popular literature in general. Indeed, since the late 40s, Greek popular literature was fully developed and organized. After taking under consideration the available lists and archives of writers, publishers and illustrators, we came to huge numbers: above one hundred publishers, above eighty writers and more or less twenty illustrators were working in the field of popular publications. It is important to point out that all these people, although they were professionals, weren't involved in this business with the same frequency and success. Most of them had a limited, transient and short presence and only a few of them had undoubtedly a leading role and of course a huge impact on the others ${ }^{8}$.

8 The main consequence of such great prosperity of the popular press was the diverse "genrification" of the magazines and booklets oriented to children and teenagers, namely many and various genres according to the themes of the narrations: stories that fictionalize the historical past, either the most recent one, for example the guerilla resistance to the German occupation, or the distant one, for example the Greek Revolution of 1821; adventures that take place in the jungle, strongly influenced by Edgar Rice Burroughs' Tarzan of The Apes; "western" stories that take place in the mythologized "Wild West"; "sport fiction" adventures, that blend football matches and crime or even spy mysteries; also science fiction magazines, comic books, booklets with fairytales and various publications starring "Karagiozis", the central character in the Greek "Theater of shadows", (a Greek version of Mr. Punch), whose roots are deep into the eastern tradition". The most common form in which these stories of various thematic directions were being released, was series of booklets with a few pages made by cheap newsprint paper. Publishing a series of stories for children and teenagers in popular magazines or newspapers was a relatively rare practice. However, the vast majority of the writers were, as expected, mainly journalists with a career in the Athenian press. Most of them didn't use their real name but a nickname, probably because they wanted to completely separate their professional careers from the slurring writing of popular literature. In many situations, Greek writers used foreign names, fictitious or real ones, mostly of American writers who were famous even in the Greek readership, because by this choice their creations would be accepted and more successful. As we can easily understand the policy of intellectual property rights wasn't developed at all ${ }^{10}$.

9 All the above suggest that Greek popular literature for children and teenagers was highly influenced by the American popular culture, not only in terms of themes and genres, but also with regard to the writing attitude and the form of the publications. If we examine the most famous titles, American influence will become even more noticeable. The magazine with the bigger commercial success and impact was entitled Little Hero. Its protagonist is a teenager, named Giorgos Thalassis (his last name probably refers to the word thalassa, the sea, a natural element that has turned into a symbol for the Modern Greek cultural identity.) Giorgos, who takes part in the guerilla resistance against the German Occupation, although he is a young man, gifted with not only great bravery, but also with the powers of a superhero and the knowledge of an almost wise man. He knows how to drive all kinds of cars, especially the military ones 
and also to pilot all kinds of aircrafts; he knows Japanese martial arts and he can speak English, German and many other languages fluently. In addition, the guerilla group in which he belongs, an organization managed by the British Allies, has equipped him with modern, even futuristic, weapons and various devices, such as a special key that open all locks. During the 798 issues of the long-lived series (from 1952 to 1967), although Giorgos kills countless enemies, not only Germans, but also Turks, Bulgarians, namely troops and spies of Greece's traditional national enemies, he remains strongly against violence, because his strong moral and religious beliefs drives him to consider war violence as a necessary evil of the struggle for freedom. Little Hero was written by Stelios Anemodouras (1917 - 2000), the most significant writer and publisher of popular literature for children and adults during $50 \mathrm{~s}$ and $60 \mathrm{~s}^{11}$.

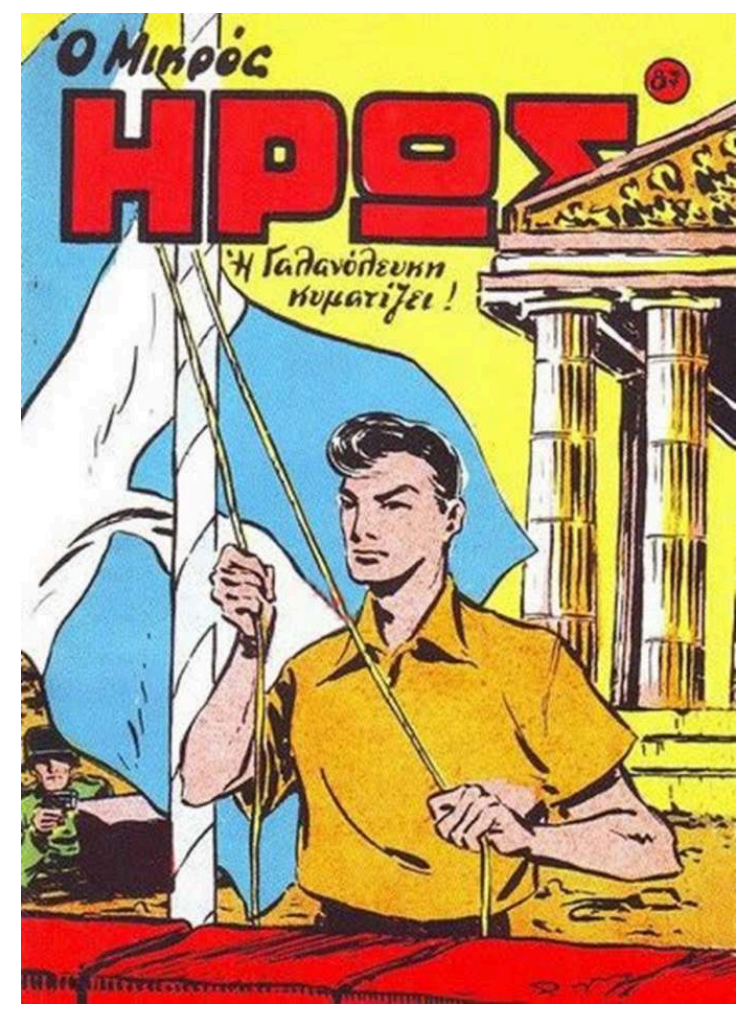

Cover of issue 83 of Little Hero; its title is indicative: The Greek flag waving

Another important series of booklets, called Ckaour Tarzan, as its title indicates, is related to one of the many Greek adaptations of E. R. Burroughs Tarzan. Certainly, it is more accurate to characterize this series as a remake of the original material, a readjustment to the conditions and mindset of the Greek urban society of the 50s. The writer of the series, Nikos Routsos (1904 - 1984), has put next to the known British Tarzan, a Greek version of him, another superhero who also lives in the jungle and who had been also raised by monkeys, but his origins are Greek and his name is Gkaour (a name that resembles to the degrading word that the Ottomans used against Greeks: gkiaouris i.e. faithless). The relations between Gkaour and Tarzan are contradictory, sometimes they are friends and some other wild competitors. Routsos' Tarzan is a tired, complicated man full of doubts, in contrary with Gkaour who is strong, brave and inspired by high moral values. The dipole of the two protagonists is framed by many other characters, human, animalistic and monstrous, a whole fantastic world, with many elements of the horror genre, conceived by Nikos Routsos, a representative 
creator of popular culture. Routsos was not only writer of popular stories, but also a lyricist of some of the most iconic Greek popular songs ${ }^{12}$.

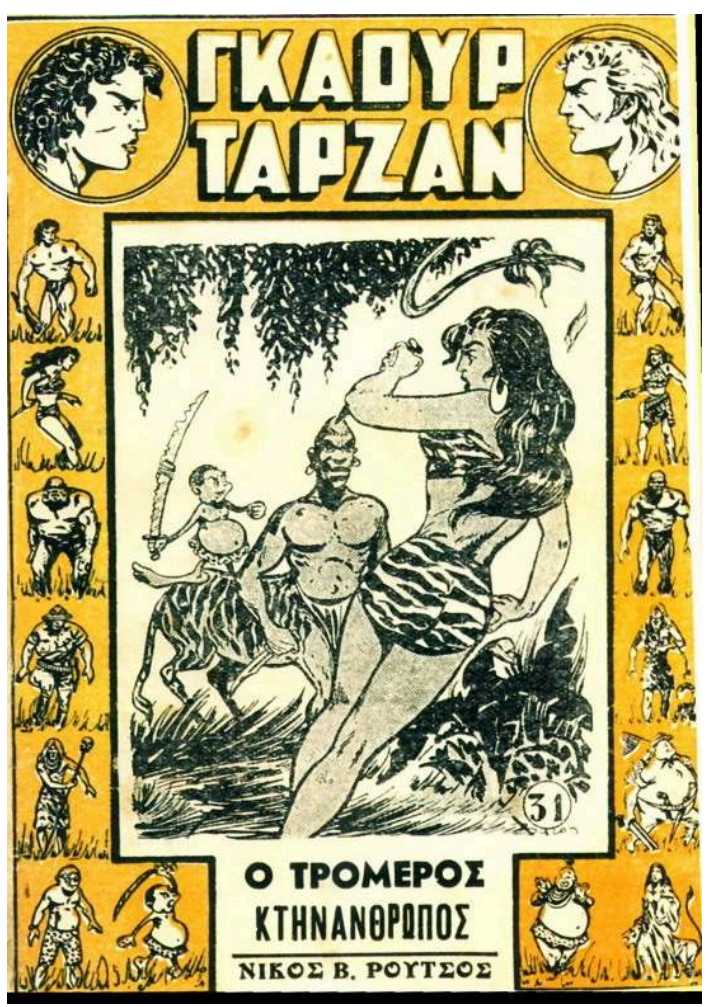

Cover of issue 31 of the second publishing period of Gkaour Tarzan. Its title is The fierce humanimal and it was released in 1952

11 The third most successful and influential magazine was Little Sheriff, created by Potis Stratikis (b. 1926). Of course, Little Sheriff belongs to the western genre and its stories take place in the Wild West, but the most original and interesting - we would say a native - point is that the protagonist, the teenager Jim Adams, has Greek origins and his real name is Dimitris Adamopoulos. In particular, Jim Adams originates from Mani, a region in Greece famous for the free spirit and the heroism of its inhabitants ${ }^{13}$. 


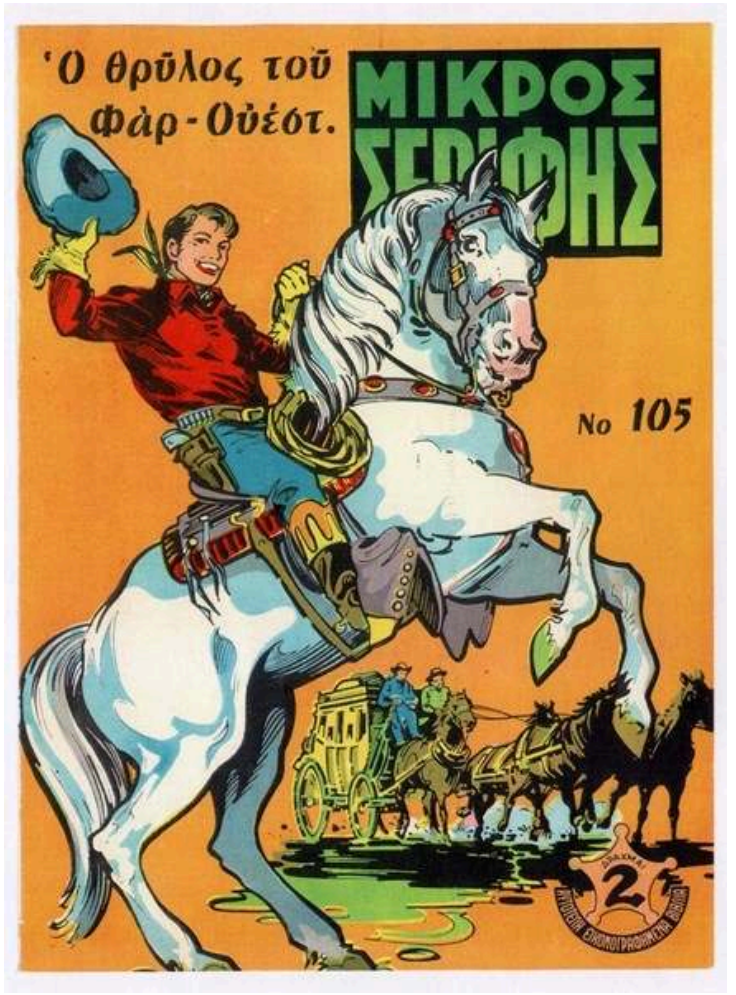

Cover of the issue 105 of Little Sheriff, entitled The Legend of Far West

Most central characters of these series are teenagers or young adults, as writers wanted to ensure that minor readers can identify with them. These young men are always accompanied by female characters of the same age, which are clearly more passive and sensitive. However, when it is required by the plot, they transform into dynamic figures who take part in the action. This ambiguous treatment that writers show towards their heroines is probably due to the efforts of the latter to satisfy the female minor readers. Of course the couple is connected by an innocent, platonic love. But this primary requirement of older children's literature for moralization leaves Nikos Routsos almost unaffected, as in Gkaour Tarzan, and also in his other work, we can find clear sexual allusions. Along with the main couple, also some stable comic characters appear, carrying a humorous tone that comes in contrary with the serious, dynamic and sometimes tragic side of the protagonists. Especially, through some specific characteristics of these comic heroes, such as gluttony, foolishness or even physical deformity, we are able to realize the deep and multivarious past of Greek popular literature and culture in general ${ }^{14}$. Lastly, in stark contrast to the positive heroes, the "bad" characters are presented as violent, inhuman, immoral and often ugly and deformed. A key element to negative characters' personality is their national or racial identity: usually in Little Hero the "bad guys" are German soldiers, in Gkaour Tarzan tribal chiefs or supernatural creatures of the jungle, while in Little Sheriff the classic figures of bandits sometimes are of Indian origin.

As it was expected, this flourishing of the popular magazines for children and teenagers provoked a powerful backlash of censorship driven not only by the "usual suspects", namely the family, the school and the Church, but also by the Left political powers who considered these magazines as part of the American propaganda. So, from the first years of the 50s, as an alternative to the pulp magazines, "high" children's literature 
appeared, written mainly by women and often directly related to educational practice. Basic principles were didacticism, attention to the specific nature of juvenile psychology and the sentient influence of traditional Greek culture, e.g. fairytales. But this effort has bore its fruit after the 70s, so until then, popular literature gained the preference of the young readers. Besides, these magazines were part of a thriving and multilateral popular culture, which also included cinema and music. Of course both cinema and music during the 50s and the 60s in Greece came under the solid influence of American popular culture; the invasion of rock and roll and jazz, generally of American dance music is a typical example for the former and the introduction of new film genres such as romantic comedy and film noir is a typical example for the latter ${ }^{15}$. Under these special circumstances, the rare situation where the Church and the Left had a similar negative approach towards American influenced popular culture is fully understood.

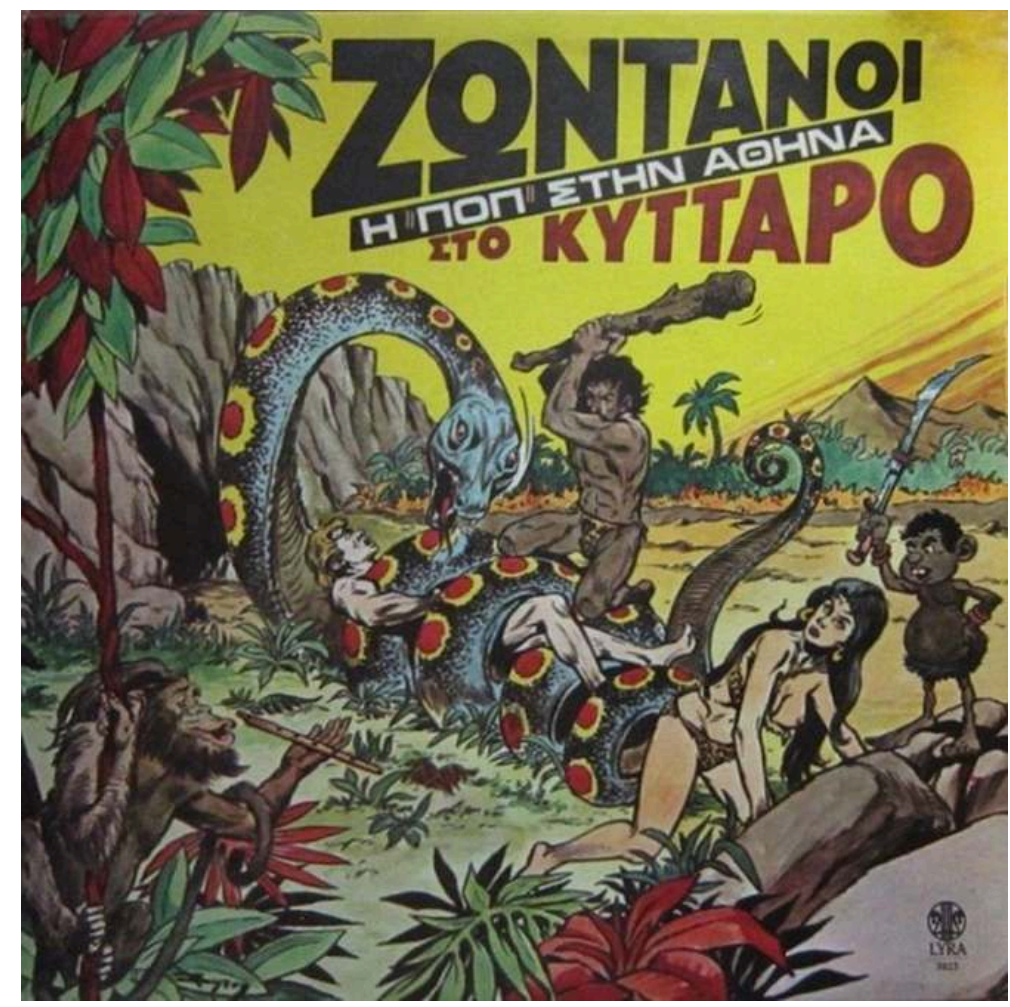

Cover of an important Greek rock music collection of 1971, depicting scenery of Gkaour Tarzan ${ }^{16}$

The most difficult part of the research concerns the identity of the readers. The first obstacle to the detection of the readership of these magazines is the mediation of many years between the period of the reading consumption until our days and the second one the lack of bibliographical and other information on the circulation of the magazines, especially in areas outside Athens. Therefore, in order to acquire some more solid information for the reading habits, we are running a project of interviewing old readers of popular magazines of the 50 s and the 60 s, who nowadays are at the age of 55 to 65 years old. More particularly, we have already conducted eight in-depth interviews: four of them were held in Athens, the capital city of Greece and the other four in Volos, a provincial town of about 150.000 habitants. Also, five of the interviewees are men, while three of them women. The analysis of this rich material, which can be considered as part of the undiscovered oral history of Greek popular press 
of the $50 \mathrm{~s}$ and the $60 \mathrm{~s}^{17}$, certainly overcomes the limits of this specific article, whereas a reference to the main points can me made here.

First of all, Little Hero was the most famous and influential magazine among the children between the age of 8 and 13 years old, boys and girls alike. The too other successful titles was Gkaour Tarzan and the Greek edition of Comics Illustrated, which made a great impression on children of that era, as colorful comics in general was something totally new for them. Children came in first contact with these magazines via interaction with older children, relatives and friends. But also these magazines were constantly in their plain sight, hanging out of the kiosks of their neighborhoods. However, because of the financial difficulties that many Greek families of that era were facing, young readers couldn't afford to buy new issues, thus they were purchasing or exchanging used magazines mainly in the corner shops that were scattered in the neighborhoods of the cities. It is important to point out that this exchanging activity functioned as a factor of socialization among children. Finally, the circle of reading and exchanging of these magazines was coming to an end, when our interlocutors were in their early teen years, due to various reasons: from a general change of interests until the lack of free time, because of the inevitable beginning of a usually demanding manual work or from shifting to other aspects of popular culture, i.e. music and cinema, until soaking up into more elaborated literature.

As many studies suggest, 60s was the last flourishing period of indigenous popular culture in Greece. Indeed, from early 70s onwards, American and Italian science fiction, superheroic and war comics which of course already were part of the pulp magazines content, prevailed over the Greek creations, as the publishers preferred them because they had lower cost. New publishing companies appeared which were familiar with the new technologies, but also synchronized to the new needs of the young readers ${ }^{18}$. But, although this interpretation for the decline of popular magazines seems the most reasonable and historically documented, even nowadays to some extent it is commonly believed that these magazines, for example Little Hero, were censored by military dictatorship regime imposed on Greece in 1967. This interpretation is the result of journalists and writers, most of them Leftists, which during the 80s saw popular literature of the $50 \mathrm{~s}$ and $60 \mathrm{~s}$ in the light of their own personal nostalgia for their childhood and adolescence. Generally, the interest in popular literature of the 50s and 60 s still today develops within a culture of nostalgia for the "good old past". Although this perspective has reached to some conclusions, should be replaced by a more spherical and complete one, which will take into account the historical, social and economic components of the phenomenon of popular literature. The present study constitutes an attempt of such an approach.

\section{BIBLIOGRAPHY}

Anagnostopoulos Vasilis, I Elliniki paidiki logotehnia (1945-1958), Athina (Kastaniotis), 1991

[The Greek children's literature (1945 - 1958), Athens (Kastaniotis publications) 1991] 
Anemodouras Stelios, Mikros Iros, T. 2-4, Athina (Ekdoseis Periodikos Tipos) 19854

[Little Hero, vol. 2-4, Athens (Periodical Press publications) 19854]

Mikros Iros (eisagogi - epimeleia: Ilias Lagios), Athina (Ekdoseis Katarti) 2001

[Little Hero (introduction and edited by Ilias Lagios), Athens (Katarti publications) 2001]

Angelopoulou Vito, “Ta paidika periodika stin Ellada, sintomi anadromi stin istoriki poreia tous”, Diadromes sto Xoro tis Logotehnias gia Paidia kai gia Neous 15 (1989), 186-190

["Magazines for children in Greece, A brief historical retrospective" Routes in the Area of Literature for Children and Adolescents, 15 (1989), 186-190]

Angelou Alkis, “To laiko anagnosma, poio laiko anagnosma;”. Eisagogi sto: Giulio Cesare Dalla Croce, Bertoldos kai Bertoldinos, Athina (Ermis) 1988

["Popular readings; which popular readings?". Introduction to: Giulio Cesare Dalla Croce , Bertoldo and Bertoldino, Athens (Hermes publications) 1988]

"To romantso tou neoellikou mithistorimatos". Eisagogi sto: Grigorios Palaiologos, O Polipathis, Athina (Ermis) 1989, ${ }^{*} 13-{ }^{*} 186$

["The romance of the Modern Greek novel". Introduction to: Grigorios Palaiologos, The Polypath, Athens (Hermes publications) $\left.1989,{ }^{*} 13-{ }^{*} 186\right]$

Baskozos Giannis, “Sizitisi me ton Kiriako Kassi”, Diavazo 354 (Augoustos 1995), 195-197

[“Talking with Kiriakos Kassis”, Diavazo (magazine) 354 (August 1995), 195-197]

Chanos Dimitris, I laiki logotehnia, T. 1 - 2, To laiko mithistorima, Athina (periodikes ekdoseis tis Maskas) 1987

[The Popular Literature, Vol. 1 - 2, the popular novel, Athens (Mask serial publications) 1987]

I laiki logotehnia, T. 3 - 4, Ta laika periodika, Athina (Ekdotis I. G. Vasileiou) 1989 - 1990

[The Popular Literature, Vol. 3 - 4, the popular magazines, Athens (published by I. G. Vasiliou) $1989-1990]$

Danforth Loring M., "Paradosi kai metasximatismos sto elliniko theatro skion", Stathis Damianakos (epimeleia), Theatro skion, paradosi kai neoterikotita, Athina (Plethron) 1993, 149-172

["Tradition and transformation in Greek shadow theater", Stathis Damianakos (ed.), Theater of shadows, tradition and modernity, Athens (Plethron publications) 1993, 149-172]

Delonis Antonis, Elliniki paidiki logotehnia, 1835 - 1985: apo tis protes rizes os tin epohi mas, Athina (Irakleitos) 19902

[Greek Children's Literature, 1835 - 1985: from its roots until today, Athens (Iraklitos publications) 19902]

Delopoulos Kiriakos, “Apo ta pezografimata gia paidia stin paidiki pezografia”, Nasos Vayenas (epimeleia), Apo ton “Leandro" ston "Luki Lara”, meletes gia thn pezografia tis periodou 1830 1880, Irakleio (Panepistimiakes Ekdoseis Kritis) 1997

["From stories intended to children to children's literature", From "Leandros" to "Lukis Laras", Nasos Vayenas (ed.), Studies on the Modern Greek prose from 1830 to 1880, Heraklion (Crete University Press) 1997] 
Denisi Sophia, To elliniko istoriko mithistorima kai o sir Walter Scott, 1830 - 1880, Athina (Kastaniotis) 1994

[The Greek historical novel and Sir Walter Scott 1830 - 1880, Athens (Kastaniotis Publications) 1994]

Dermentzopoulos Christos, To listriko mithistorima stin Ellada: mythoi - anaparastaseis ideologia, Athina (Plethron) 1997

[The bandit novel in Greece: Myths - representations - ideology, Athens (Plethron publications) 1997]

Diamantis Apostolos, “I Maska kai to Mistirion”, Eleftherotipia: Epsilon, 276 (Ioulios 1996)

["The Mask and the Mystery," Eleftherotypia: Epsilon (magazine), 276 (July 1996)]

Gkotsi Georgia, "I mithistoria ton Apokrifon, simvoli stin perigrafi enos eidous", Vayenas (epim.), $1997,149-168^{19}$

["The mystery novel, contribution to the description of this (literary) genre", Vayenas (ed.) 1997, 149-168]

Eisagogi sto: Ioannis Kondilakis, Oi athlioi ton Athinon, Athina (Nefeli), 1999, 7-48

[Introduction to Ioannis Kondilakis, The miserables of Athens, Athens (Nefeli publications) 1999, $7-48]$

Grammatikos Nikos, “Sinenteuksi me ton Dimitri Chano”, Tetarto, 24 (Aprilios 1987), 15-19

[“Interview with Dimitris Chanos”, Tetarto (magazine), 24 (April 1987), 15-19]

Kanatsouli Meni, "Hioumoristikoi haraktires kai tipoi laikon anagnosmaton", Diavazo 336 (1994), 51-56

[“Humorous Characters and Types of children's books”, Diavazo (magazine) 336 (1994), 51-56]

Kassis Kyriakos, Elliniki paralogotehnia kai comics (1598-1998), Athina (I.CH.O.R. \& A.L.L.E.A.S.) 1998

[Greek popular fiction and comics (1598 - 1998), Athens (I.CH.O.R. \& A.L.L.E.A.S.) 1998]

Katsapis Costas, Ihoi kai apoihoi, I koinoniki istoria tou rock n roll fainomenou stin Ellada, 1956-1967, Athina (Istoriko Arxheio Ellinikis Neolaias) 2007

[Sounds and Echoes, social history of the rock and roll phenomenon in Greece,1956-1967, Athens (General Secretariat for Youth) 2007]

The whole book is available to: http://www.iaen.gr/

ihoi_kai_apoihoi__koinoniki_istoria_tou_rok_en_rol_fainomenou_stin_ellada__1956_1967-

b-70.html. Accessed May 29, 2015

Kouzeli Lamprini, “I Maska exei ti diki tis istoria”, Vima (July 2012)

["The Mask has its own story," Vima (newspaper) (July 2012)]

Available to: http://www.tovima.gr/books-ideas/article/?aid=468564. Accessed May 29, 2015

Moullas Panagiotis, O horos tou efimerou, stoiheia gia thn paralogotehnia tou 19ou ai., Athina (Sokolis) 2007

[The space of the ephemeral, elements of popular literature of the 19th century, Athens (Sokolis publications) 2007] 
Philippou Philippos, O Giannis Maris, I epohi tou kai I astinomiki logotehnia

[Yannis Maris, his era and Greek crime fiction]

Available to: http://crimefictionclubgr.wordpress.com/opinion-greek-detective-stories/ marisss/. Accessed May 29, 2015

Politis Alexis, “Anazitontas tin pezografia kai tous pezografous, 1830 - 1880”, Asteris Argiriou k. a. (epim.), o ellinikos kosmos anamesa stin anatoli kai ti disi, 1453 - 1981, A', Athina (Ellinika Grammata) 1999, 85-96

["Searching about the prose and the writers, 1830 - 1880", Asterios Argyriou etc. (ed.), The Greek world between the East and the West from 1453 to 1981, Vol. 1, Athens (Ellinika Grammata publications) 1999, 85-96]

“Anazitontas orismenous stathmous stin ekseliksi tis pezografias tou 19ou ai.", Nea Estia 157 (2005), 557-568]

["Searching for some milestones of 19th century prose”, Nea Estia (magazine) 157 (2005), 557-568]

"To mithistorima ton aston, skepseis gia tis aparhes tou neoellinikou mithistorimatos, Omilos Meletis tou Neoellinikou Diafotismou, Neoelliniki paideia kai koinonia, Athina 1995, 67-105

["The Fairytale of the bourgeois, thoughts on the origins of modern Greek novel", Study Group of the (Modern) Greek Enlightenment, Modern Greek culture and society, Athens 1995, 97-105]

Routsos Nikos, “To tabou tis frikis”, Tarzan 1, Athina (Arkyra) 2010 (reprint) ${ }^{20}$

["Taboo of horror", Tarzan 1, Athens (Agkyra) 2010 (reprint)]

“O Gkaour timorei”, Gkaour Tarzan 4, Athina (Agkyra) h.h.

[“Gkaour punishes”, Gkaour Tarzan 4, Athens (Agkyra) n.d.]

“To fteroto teras", Gkaour Tarzan 8, Athina (Agkyra) h.h.

["The flying monster", Gkaour Tarzan 8, Athens (Agkyra) n.d.

"Epanastasi sti zougkla", Gkaour Tarzan 17, Athina (Agkyra) h.h.

["Revolution in the jungle", Gkaour Tarzan 17, Athens (Agkyra) n.d.

“Orkos sto theo Kraoumpa", Gkaour Tarzan 19, Athina (Agkyra) h.h.

["Vow to god Kraoumpa", Gkaour Tarzan 19, Athens (Agkyra) n.d.

“Oi arravones tou Pokopiko”, Gkaour Tarzan 48, Athina (Agkyra) h.h.

[“Pokopiko's engangements", Gkaour Tarzan 48, Athina (Agkyra) n.d.]

“To chalivdino teras", Gkaour Tarzan 78, Athina (Agkyra) h.h.

["The steel monster", Gkaour Tarzan 78, Athens (Agkira) n.d.]

“To Vasileio tou Gkaour”, Tarzan, nees peripeteies 30, Athina (Agkyra) 2010 (anatiposi, proti ekdosi: 1951)

[“Gkaour's Kingdom”, Tarzan, new adventures 30, Athens (Agkyra) 2010 (reprint, year of 1st edition: 1951)]

Routsos Nikos D., Anemodouras Stelios, Stratikis Potis, Marmaridis Giorgos, Anthologio ellinikon anagnosmaton, epimeleia: Ilias Lagios, Athina (Katarti) 2008

[An Anthology of Greek readings (ed. Ilias Lagios), Athens (katarti publications) 2008] 
Soldatos Giannis, Istoria tou Ellinikou Kinomatografou, A' tomos (1900 - 1967), Athina (Aigokeros) 81999

[History of the Greek Cinema, Vol. 1 (1900 - 1967), Athens (Aigokeros publications) 81999] Thompson Paul, The Voice of The Past, Oral History, Oxford (Oxford University Press) 32000 Tonnet Henri, Meletes gia tin neoellhini pezografia (metafrasi: Foteini Vlachopoulou), Athina (Nisides) 2009

[Studies on Modern Greek prose (translation: Fotini Vlachopoulou), Athens (Nisides publications) 2009]

Vlachos Giorgos, “Ta iroika ellinopoula tis Diasporas”, Tetarto 41, 42 (1988)

"The "Heroic Greek children of the Diaspora", Tetarto (magazine) 85 (1988) (I found this article on the internet, and the page numbers are not visible)

Mia istoria sta eksofilla, ellinika laika periodika, 1948-1968

[A story on the covers: Greek popular magazines for children (1948-1968)]

(The leaflet for the exhibition of covers of children's and teenagers' magazines; this exhibition took place between 12/18/2006 and 01/20/2007 in Psichiko, Athens. The presentation of the material is based on the various genres of the magazines).

A blog dedicated to Little Hero, called Ta Mikroiroika (“Littleheroics"): http://

tamikroirwika.blogspot.gr/. Accessed May 29, 2015

O Zouglografos, o rembetis, o paramithas kos Nikos, 15 Dekemvriou 2011

[Nikos Routsos, the junglewriter, the rembetis and the storyteller, December 15, 2011]

Available to: http://dinothesaurus.blogspot.gr/2011/12/blog-post_15.html . Accessed May 29, 2015

Palia periodika me yli poikili, 18 Ianouariou 2012

[Old magazines with diverse material, January 18, 2012]

Available to: http://dinothesaurus.blogspot.gr/2012/01/blog-post_18.html. Accessed May 29, 2015

O Giannis Maris kai ta eikonografimena astinomika serial sto harti, 31 Maiou 2012

[Giannis Maris and the illustrated crime fiction series, May 31, 2012]

Available to: http://paralogotechniasanagnosma.blogspot.gr/2012/05/13.html. Accessed May 29, 2015

Voutouris Pantelis, “Os Eis kathreptin”, protaseis kai ipotheseis gia tin elliniki pezografia tou 19ou ai., Athina (Nefeli) 1995

["Os Eis Kathreptin", proposals and assumptions on Greek prose of the 19th century, Athens (Nefeli Publications) 1995]

Zervou Alexandra, Logokrisia kai antistaseis sta keimena ton paidikon mas hronon, Athina (Odysseas) 1992

[Censorship and resistance in the books of our childhood, Athens (Odysseas publications) 1992] Zoiopoulos Nikos, Kai h zougla thelei ton Gkaour tis, 19 Maiou 2012

The jungle also needs its Gkaour, May 19, 2012 
Available to: http://dinostalgicus.blogspot.gr/2012/05/blog-post.html. Accessed May 29, 2015

Sources of the pictures

Page

4 http://anemi.lib.uoc.gr/metadata/9/d/4/metadata-312-0000149.tkl

5 http://anemi.lib.uoc.gr/metadata/5/c/a/

metadata-8a030266a7f8abae3b3f22cbcf49cc53_1269333260.tkl

6 http://www.tovima.gr/relatedarticles/article/?aid=87806

7 http://dinothesaurus.blogspot.gr/2011/05/blog-post_08.html

12 http://www.trolleei.gr/index.php/almpoum/1236-o-mikros-iros

$14 \mathrm{http}: / /$ paralogotechniasanagnosma.blogspot.gr/2012/05/31.html

15 http://www.mancode.gr/articles/2012/3/19/mikros-serifis-no1469-to-kokkino-vouno/

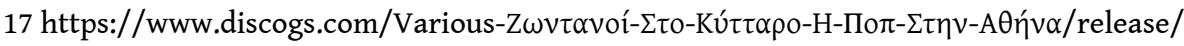

5132619

All sources accessed May 30, 2015

\section{NOTES}

1. An in-depth presentation of the Greek popular literature between $16^{\text {th }}$ and $18^{\text {th }}$ century can be found in Alkis Angelou, "Popular readings; which popular readings?", an introduction to the critical edition of the Greek translations of the works Bertoldo and Bertoldino by Giulio Cesare Dalla Croce: Giulio Cesare Dalla Croce, Bertoldo and Bertoldino, Athens (Hermes publications) 1988, 9*-200*. Note: Almost all bibliographic sources that were used in this article are Greek-speaking, because its central subject is a mainly historical retrospective of Greek popular fiction. Therefore, we have chosen the following method: the references in the footnotes of the main text are translated in English, so English-speaking readers can understand the contents of the studies referred. But, in the bibliography that follows, the data of the sources is written in Greek with Latin characters, followed by the English translation.

2. Since the early 90s, academic literary and historical research in Greece has developed an increasingly strongest interest for the original and also the translated prose of the 19th century, a field that during past years had remained undiscovered and full of misconceptions. In most of these studies, "high" literature compared with the popular one. Some key studies are (in chronological order): Alkis Angelou, "The romance of the Greek novel”. Introduction to: Grigorios Palaiologos, The Polypath, Athens (Hermes publications) 1989, *13-*186; Sophia Denisi, The Greek historical novel and Sir Walter Scott 1830-1880, Athens (Kastaniotis Publications) 1994; Pantelis Voutouris, "Os Eis Kathreptin": Proposals and assumptions on Greek prose of the 19th century, Athens (Nefeli Publications) 1995; Alexis Politis, "The Fairytale of the bourgeois. Thoughts on the origins of modern Greek novel". Study Group of the (Modern) Greek Enlightenment., Modern Greek culture and society, Athens 1995, 97-105; Nasos Yayenas (ed.), From "Leandros" to "Lukis Laras", studies on the Modern Greek prose from 1830 to 1880 , Heraklion (Crete University Press) 1997; Alexis Politis, "Searching about the prose and the writers, 1830-1880", Asterios Argyriou etc. (ed.), The Greek world between the East and the West from 1453 to 1981, A', Athens (Ellinika Grammata publications) 1999, 85-96; Panagiotis Moullas, The space of the ephemeral, elements of popular literature of the 19th century, Athens (Sokolis publications) 2007. 
3. For further information on the changes in Greek popular literature of the late 19th century: Moullas (2007) 165-172; Alexis Politis, "Searching for some milestones of $19^{\text {th }}$ century prose", Nea Estia 157 (2005), 557-568.

The most significant articles and studies about Greek "Mystery novel" are (in chronological order): Voutouris 1995, 174-198; Zeta Gkotsi, "The mystery novel, contribution to the description of this (literary) genre", Vayenas (ed.) 1997, 149-168; Gkotsi, Introduction to Ioannis Kondilakis, The miserables of Athens, Athens (Nefeli) 1999, 7-48; Henri Tonnet, Studies on Modern Greek prose (translation: Fotini Vlachopoulou), Athens (Nisides publications) 2009, 232-296

4. For further information on "bandit novel": Christos Dermentzopoulos, The bandit novel in Greece: Myths - representations - ideology, Athens (Plethron) 1997.

For more information on the development of Greek popular literature during early $20^{\text {th }}$ century: Dermentzopoulos, 46-85; Dimitris Chanos, Popular Literature, Vol. 2, Athens (Mask serial publications) $1987,11-12,17-20$

5. On popular "family magazines" in Greece, their identity and history, see: Dimitris Chanos, The Popular Literature, Vol. 3, Athens (published by I. G. Vasiliou) 1989; Giorgos Vlachos, "Old magazines with diverse material", January 18, 2012. Available to: http:// dinothesaurus.blogspot.gr/2012/01/blog-post_18.html

6. Further information on Greek crime fiction and especially the two main crime fiction popular magazines, Mask and Mystery: Dimitris Chanos, The Popular Literature, Vol. I, Athens (Mask serial publications), 243-245; Kyriakos Kassis, Greek popular fiction and comics (1598 - 1998), Athens (I.CH.O.R. \& A.L.L.E.A.S.) 1998, 23-24, 29, 145-148, 164; Nikos Grammatikos, "Interview with Dimitris Chanos", Tetarto (magazine), 24 (April, 1987); 15-19. Apostolos Diamantis, "The Mask and the Mystery", Eleftherotypia: Epsilon (magazine), 276 (July 1996); Lamprini Kouzelis, "The Mask has its own story", Vima newspaper (July 2012). Available to: http://www.tovima.gr/books-ideas/ article/?aid=468564; Philippos Philippou, Yannis Maris, his era and Greek crime fiction. Available to: http://crimefictionclubgr.wordpress.com/opinion-greek-detective-stories/marisss/; Giorgos Vlachos, Giannis Maris and the illustrated crime fiction series, May 21, 2012. Available to: http:// paralogotechniasanagnosma.blogspot.gr/2012/05/13.html

7. Some of the most considerable studies and articles about Greek literature for children and teenagers during that era (in chronological order): Vito Angelopoulou "Magazines for Children in Greece, A Brief historical Retrospective", Routes in the Area of Literature for Children and Adolescents 15 (1989), 186-190; Antonis Delonis, Greek Children's Literature, 1835-1985: from its roots until today, Athens (Iraklitos publications) ${ }^{2} 1990$; Alexandra Zervou, Censorship and resistance in the books of our childhood, Athens (Odysseas publications) 1992; Vasilis D. Anagnostopoulos, The Greek Children's Literature (1945 - 1958), Athens (Kastaniotis publications) 1991; Kiriakos Delopoulos, "From stories intended to children to children's literature", Vayenas (ed.) 1997, 227-234.

8. The two main researchers of Greek popular culture, Dimitris Chanos and Kiriakos Kassis had included lists of Greek popular literature editions (books, magazines, newspaper and booklets) in their studies; more specifically: Kassis (1998), 104-207 and Chanos, Vol. 4, (about the magazines). Also in Chanos' Popular Literature, we find reprinted lists originally composed by publishers and bookstores during the 50 s and the 60 s, or even earlier. The conclusions are based on the study of all the available lists. However, we should note that the validity of these sources is not affirmed.

9. Further information on the "gentrification" of the Greek popular literature for children and teenagers during the 50s and the 60s: Giorgos Vlachos, A story on the covers: Greek popular magazines for children (1948-1968) (the leaflet for the exhibition of covers of children's and teenagers' magazines; this exhibition took place between 12/18/2006 and 01/20/2007 in Psichiko, Athens. The presentation of the material is based on the various genres of the magazines). More information about the shift of the publishers and authors towards a readership which consisted by children and teenagers: Giorgos Vlachos, "The Heroic Greek children of the Diaspora", Tetarto, 41, 42 (1988) [I found this article on the internet, and the page numbers are not visible]. 
For some information on the publications starring Karagiozis, see: Loring M. Danforth, "Tradition and transformation in Greek shadow theater", Stathis Damianakos (ed.), Theater of shadows, tradition and modernity, Athens (Plethron publications) 1993, 149-172. In the end of the article, we can find a complete bibliography of studies regarding the Greek shadow theater. However, a comprehensive study on the relationship between Greek shadow theater and the field of the publication has yet to be conducted.

10. In the second volume of his study The Greek Popular Culture, Dimitris Chanos gives some biographical data about many writers in alphabetical order: Chanos, Vol. 2, 123-241.

11. This information about Little Hero was based mainly on: a. a selection of some issues of the magazine itself, more specifically from issue 9 to issue 32 (Stelios Anemodouras, Little Hero, vol. 2-4, $\left.{ }^{4} 1985\right)$ b. Giorgos Vlachos' blog that is totally dedicated to Little Hero: http:// tamikroirwika.blogspot.gr/c. Ilias Lagios' introduction to an anthology of Little Hero's stories [Stelios Anemodouras, Little Hero (introduction and edited by Ilias Lagios), Athens (Katarti publications) 2001, 9-77].

Information on the life and activities of Stelios Anemodouras can be found in Anemodouras, 2001: 383-405, Chanos, Vol. 2, 124-125.

12. The information about Gkaour Tarzan was mainly based on: a. a selection of nine issues of the magazine itself (detailed bibliographical description can be found in the "Bibliography" section) b. Nikos Zoiopoulos, "the jungle also needs its Gkaour" May 10, 2012. Available to: http:// dinostalgicus.blogspot.gr/2012/05/blog-post.html.

Information on the life and activity of Nikos Routsos can be found: Nikos D. Routsos, Stelios Anemodouras, Potis Stratikis, Giorgos Marmaridis, An Anthology of Greek readings (introduction and edited by Ilias Lagios), Athens (katarti publications) 2008, 21, Chanos, Vol 2, 195, Giorgos Vlachos, Nikos Routsos, the junglewriter, the rembetis and the storyteller, December 15, 2012. Available to: http://dinothesaurus.blogspot.gr/2011/12/blog-post_15.html

13. More information on Little Sheriff and Potis Stratikis: Routsos etc., 2008, 213. Chanos, Vol. 2, 202.

14. On the comic heroes in popular literature for children and teenagers, see: Meni Kanatsouli, "Humorous Characters and Types of children's books", Diavazo (magazine) 336 (1994), 51-56.

15. On the importation of pop music in general, mainly rock music in Greece during the 50s and the 60s, see: Costas Katsapis, Sounds and Echoes, social history of the rock and roll phenomenon in Greece, Athens (General Secretariat for Youth) 2007. On Greek cinema during the 50s and the 60s: Giannis Soldatos, History of the Greek Cinema, Vol. 1 (1900 - 1967), Athens (Aigokeros publications) ${ }^{8} 1999$

16. Various, Zontanoi sto Kittaro, Greece 1971; compilation of three 7" vinyl: Zodiac - 88023, Zodiac - SYZP 88023, Zodiac - ZS 8252

17. The theoretical frame of this project is mainly based on: Paul Thompson, The Voice of The Past, Oral History, Oxford (Oxford University Press) ${ }^{3} 2000$.

18. The decline of indigenous Greek popular literature during the end of the 60s has not yet been the subject of a special study, so conclusions arise mainly from references found in articles, tributes and interviews dispersed in magazines and on the Internet. Therefore, it's difficult to give specific bibliographical details. For example, Kiriakos Kassis in an interview admits that "From 1960 onwards, the sci-fi comics simply translated the successful American series." [Giannis Baskozos, “Talking with Kiriakos Kassis”, Diavazo (magazine) 354 (August 1995), 195-197]. 19. In this article the author is written as "Zeta Gkotsi"

20. Gkaour Tarzan is a rare and expensive magazine; especially its original issues of the 50s are collective items. So, it's not only difficult to trace issues, but to get bibliographical info about them. The most common missing element is the publishing year. 


\section{ABSTRACTS}

Although many academic scholars in the fields of literature and history, especially from the 90s onwards, have shown an advanced interest for 19th century Greek popular novel, popular literature of the 20th century remains a little-researched academic field. More specifically, the flourishing era of the $50 \mathrm{~s}$ and the $60 \mathrm{~s}$ is still unexplored. During that period, popular press in Greece developed and was organized, mainly via magazines and booklets oriented to children and teenagers. So, in this case, the reflection about popular literature is combined with the problematic on children literature. But, popular and children's fiction have a long and parallel presence in Modern Greek cultural history, which dates back before the 19th century.

In this study, we make a spherical presentation of the Greek popular magazines for children and teenagers during the $50 \mathrm{~s}$ and the $60 \mathrm{~s}$. Therefore, the intertextual analysis of the fictional characters is connected with the social, political and economic aspects of the magazines: the reactions of intellectuals, the ecclesiastical circles and the main political forces of that time; the dominant and versatile influence of American popular culture on the Greek press, music and cinema; above all, the readership's identity and mindset.

\section{INDEX}

Keywords: popular fiction, popular culture, cultural studies, Modern Greek literature, Greek popular culture, literary history, literature for children and teenagers

\section{AUTHOR}

\section{NIKOS FILIPPAIOS}

Nikos Filippaios was born in Volos, Greece, in 1980. He received his degree in Greek language and literature at the University of Ioannina in 2004 and his MA in Modern Greek literature at the University of Crete in 2008. The subject of his MA thesis was the Greek popular novel of the 19th century which fictionalized the Greek War of Independence (1821-1829), through a historical and sociological perspective. From 2014, he is a PhD candidate in the department of Fine Arts and Art Sciences of University of Ioannina. His study concerns the popular literature magazines for children and adolescence during 50s and 60s in Greece, more specifically their various social, political and economic correlations. Thus, his academic interests include Modern Greek literature, literature for children and teenagers, popular culture and cultural studies. He has participated in two conferences ("The birth of mass culture in Europe", Debrecen, 11-13 December 2014 - "Diversity in 20th- and 21st-century Greek popular culture(s) and media", Oxford, 14 March 2015), with announcements concerning his PhD thesis. 